\title{
Middle Welsh yn in Verbal Noun Phrases ${ }^{\mathrm{I}}$
}

\author{
Ricarda Scherschel
}

\section{Introduction}

In Middle Welsh the verbal noun used with the particle $y n$ is most frequently associated with the periphrastic tense of bod $+y n+$ verbal noun. This periphrasis has been discussed widely in the literature in connection with aspectual features and progressivity (inter alia Falileyev (1994), Mittendorf \& Poppe (2000), and Ronan $(2006,2012)$ for Middle Welsh). Other uses of $y n+$ verbal noun have been touched upon in the literature but the research on these is more limited than that on aspectual constructions. Various scholars (e.g. Evans 1964: 215; Le Roux 1957: 350; Mac Cana 1999: 157; Mezger 1931: 238; Morris-Jones 1955: 394; Schumacher 2000: 19) have described non-aspectual uses of $y n+$ verbal noun as being similar to participles.

This article focuses on non-periphrastic uses of $y n+$ verbal noun. Some of these non-aspectual uses have been identified and discussed by Borsley et al. (2007), Evans (1964), Mac Cana (1999), Mezger (1931), Mittendorf \& Poppe (2000), Scherschel et al. (2018), Sturzer (2001), and Shisha-Halevy (2016), but an extensive study or overview of them remains a desideratum. This article aims to provide a (preliminary) system of classification and to discuss the limitations of such categorisation.

The article is structured in the following way. Firstly, the different uses of $y n+$ verbal noun in Middle Welsh are illustrated and discussed. Secondly, the use of $y n+$ verbal noun is analysed in the light of the typological approach of van der Auwera \& Malchukov (2005), which deals with the semantic mapping of adjectival secondary predicate structures. The third section tests the Middle Welsh data collected against the suggested typological framework.

\section{Non-aspectual uses of $y n+$ verbal noun}

\subsection{Previous scholarship on non-aspectual $y n+$ verbal noun}

In the available literature, we can find descriptions of and references to the use of $y n+$ verbal noun in adjunct, presentative, subpredicate and epitactic (or absolute) constructions. For Modern Welsh, Shisha-Halevy (2009) suggests analysing $y n+$ verbal noun as 'converbs' and adds adnominal modification by $y n+$ verbal noun to the range of usage. For Middle Welsh, I also posit the adnominal use of $y n+$ verbal

1. I am grateful to Erich Poppe, Elena Parina and Mícheál Hoyne for helpful comments and discussion and improvements to my English. All remaining errors are my own. 
noun, although this analysis has often been obscured by highlighting the (near-) equivalence of $y n+$ verbal noun with participles. I will discuss the available literature for each of the possible constructions identified in turn.

\subsubsection{Adjunct}

Generally, adjunct relations are non-obligatory modifications which modify a phrase or the entire sentence. The most frequent type of adjunct relations are adverbials, however, the data does not provide an example of $y n$ + verbal noun as a sentence-modifying adverbial expressing typical adverbial relations of, for example, cause, condition, or time. Rather than sentence-modifying adjuncts, Borsley et al. (2007:303) have pointed out that "[i]n Middle Welsh, the most frequent use of $y n+$ verb-noun is as an adjunct, often to a noun phrase (cf. modern French en)" as shown in (1), taken from Borsley et al. (2007:303), and in (2) found in the Red Book version of Bruty Brenhinedd. However, their classification is not adopted here. Instead, examples (1) and (2) are analysed as immediate perception complements. Section 2.2 discusses the term adjunct from a perspective of general linguistics and the integration of immediate perception complements in the proposed framework.

(1) ...ef a welei varchawc yn dyfot yn y erbyn...

...he saw a knight coming towards him...

(P 61.17-8)

(2) A phan wyl gwyr rufein y brytanyeit yn dyuot attunt. gwisgaw eu harueu a wnaethant. And when the men of Rome saw the British coming towards them they took up their arms.

(BB-RB 77.29-31)

\subsubsection{Presentative}

The term presentative was introduced to Middle Welsh syntactic descriptions in Shisha-Halevy (1999) and taken up again for Modern Welsh in Shisha-Halevy (2016). Presentational constructions serve to introduce a new referent to the discourse and constitute a subtype of thetic statements (Sasse 1987; Lambrecht 1994), see ex. (3). From a rather narratological point of view, this construction has been described by Mezger (1931: 241) as characterising "etwas Unerwartetes, Überraschendes" ('something unexpected, surprising'). This notion is found again in Sturzer (2001) who investigates sentence-initial uses of llyma and nachaf as well as the so-called miratives where an adverbial phrase precedes llyma and nachaf. Cases of mirative llyma and nachaf express sudden or unexpected actions or events. Both constructions consists of an interjection (llyma or nachaf), a (pro)noun and $y n$ + verbal noun. 
The order of the constituents is not fully fixed, but usually the (pro)noun precedes the $y n+$ verbal noun phrase; see (4) and (5):

(3) Nachaf y kawr hwnnw yn dyuot ar y veinuet or kewri ereill ygyt ac ef... Behold, this giant coming with twenty of the other giants with him...

(BB-RB 46.4-6)

(4) Ac ar hynny llyma y dryw yn seuyll ar wwrd y llog.

And at that, indeed, a wren was standing on the deck of the boat.

(PKM 80.19-20)

(5) Ac val yd oedynt velly nachaf karw yn kerdet heibaw.

And as they were so, behold, a deer went past.

(BB-RB 32.29-30)

\subsubsection{Subpredicate}

Certain uses of $y n+$ verbal noun have been labelled "subpredicate" or "participle" (Evans 1964: 215). Mittendorf \& Poppe (2000:124) explore this term further using it as a very general umbrella term. Some of the examples they provide fall into other categories proposed here. By "subpredicate" or secondary predication, I understand here instances which express a second action in addition to the action expressed by the main predicate. In addition they show participant-orientation to one of the participants of the superordinate clause and express co-temporality with the superordinate clause. Section 2.2 and 3 discuss the integration of these constructions in the proposed framework. The difficulty of differentiating between aspectual uses of $y n$ + verbal noun and secondary predication is often encountered in sentences which use a form of bod 'be', a locative phrase and $y n+$ verbal noun. In other words, when a locative phrase is inserted into the expected syntagm of bod $+y n+$ verbal noun to form a periphrastic tense, it is possible to interpret the construction in a different way. In (6), we are dealing with two predications rather than just one. It expresses two predications, namely, 1) Saint Aydan is in the church and 2) Saint Aydan prays, rather than one predication that Saint Aydan is praying in his own church. The former interpretation rests on word order, and the intervening locative phrase yn y eglwys is understood as blocking an aspectual reading (cf. Scherschel et al. 2018: 38-39); see (7) with the intervening locative phrase yn ynys brydein).

(6) Yr oed Aydan sant yn y eglwys ehun yn dinas Gwernin yn gwediaw.

Saint Aydan was in his own church in the town of Gwernin praying.

(BDe 6.33-4) 
(7) Ac yn yr amser hwnnw yd oedynt yn ynys brydein yn talu enryded y'r geudwyweu. Wyth temyl ar hugeint a their prif demyl.

And in that time there were in the island of Britain paying reverence to the false gods 28 temples and three main temples.

(BB-RB 87.41-4)

\subsubsection{Absolute}

Absolute constructions have been paid the most attention by Mac Cana (1999), who discusses these constructions in relation to narrative syntax in Middle Welsh. Mac Cana applies the term 'epitaxis' to constructions such as (8)-(9), taking over the term from Lambert (1978) who follows Gagnepain (1963).

(8) Kanys mwy y karyssei ef hi nor rei ereill eiryoet. a hitheu yn y dremygu ynteu yn vwy nor rei ereill.

Since he loved her more than the others and she despised (lit. despising) him more than the others.

(BB-RB 52.37-40)

(9) Ac ygyt a hynny hefyt yd oed y gwas Jeuanc bonhedickafyg groec o barth y dat. y vam ynteu a hanoed o genedyl droea. Ac [ø] yn ymdiret yndunt.

And moreover, the young man was the most noble in Greece from his father's side, his mother was descended from the cenedl of Troy, and he had (lit. having) confidence in them [the cenedl of Pyrrhus].

(BB-RB 33.11-4)

He describes these constructions as "nominal phrases formally coordinated but functionally subordinated and normally embodying an anaphoric reference" (Mac Cana 1999: 163-4). In a grammar of Modern Welsh, dating to the end of the $19^{\text {th }}$ century, Anwyl had already pointed out this usage in Modern Welsh and applied the term "absolute clauses" to this construction type (1899:121-2). As the term 'absolute clauses' is commonly used in linguistics, I will adopt it to refer to this type of usage.

As can be seen in the examples above, (8) bears an anaphoric reference, hitheu, which is co-referential with the object of the preceding clause, while in (9) the subject of the $y n$ + verbal noun phrase has to be inferred from the context, namely as the subject of the preceding clause, gwas (see section 3 for further discussion).

\subsubsection{Adnominal}

The use of $y n+$ verbal noun to modify nouns is not well documented in the literature although the translations provided for textual examples sometimes suggest 
that this analysis has been preferred. An additional drawback in the translations, especially in English ones, is that the present participle may be used. Thus, the adnominal modification is often obscured by the translation strategy as the participle may stand for adnominal or adverbial modification; see (10):

(10) Brutus tywyssawc gwedillon kenedyl droed. yn anuon annerch y bandrassus vrenhin groec. Brutus, prince of the remnants of the tribe of Troy, who sends/sending greetings to Pandrassus, king of Greece.

(BB-RB 33.40-1)

\subsection{Adjustments to the five-way classification}

The above suggests five non-aspectual types of usage for $y n+$ verbal noun (adjunct, presentative, subpredicate, absolute and adnominal) which, so far, have not been systematically investigated or interrelated. In contrast to this, the following analysis pursues a four-way classification for non-aspectual constructions of $y n+$ verbal noun. Accordingly, the five groups derived from previous scholarship and introduced above will be rearranged to result in a four-type-classification of adjuncts, complements, adnominal modifications and absolutes.

Firstly, a few remarks on the notion of adjunct as applied in this paper are in order. Adjunct relations as understood here include both so-called event-oriented adjuncts and participant-oriented adjuncts. Event-oriented adjuncts are what is generally understood as adverbial clauses expressing for example time, cause or purpose. Participant-oriented adjuncts make up a special field of research and relevant cases have been labelled differently, as, for example, 'secondary predicates', 'predicative attribute' or 'predicative adjunct', 'co-predicate', 'co-predicative' and 'depictive' (Himmelmann \& Schultze-Berndt 2005: 4). The main distinction between event-oriented adjuncts and participant-oriented adjuncts then is that the former express the circumstances under which the superordinate clause takes place while the latter show a connection towards a participant of the superordinate clause as well as co-temporality with the event expressed in the superordinate clause. In addition to participant-oriented adjuncts defined in Himmelmann \& Schultze-Berndt (2005), Fabricius-Hansen \& Haug (2012:1-2) describe co-eventive adjuncts which are co-located, co-temporal and participant-connected to the eventuality of the superordinate clause. Co-eventive adjuncts are set apart from participant-oriented adjuncts by additional adverbial semantics they carry, such as attending circumstances or cause. Under the current framework cases like (6) and (7) are therefore analysed as participant-oriented adjuncts. This type of 'sub-predicates' (group 3) will be collapsed with adjuncts. Generally then, adjuncts include event-oriented (adverbial), co-eventive and participant-oriented adjuncts. The data does not provide 
clear instances of $y n+$ verbal noun as purely event-oriented adjuncts. The data suggests rather that co-eventive adjuncts occupy a position between event-oriented and participant-oriented adjuncts as they carry features of participant-orientation and temporal overlap as well as adverbial semantics like attending circumstances or cause. In the following 'sub-predicate' or 'secondary predicate' is also used as a cover term for participant-oriented and co-eventive adjuncts.

The type of adjuncts to noun phrases discussed by Borsley et al. (2007:303) (varchawc yn dyfot), however, is reanalysed as a complement relation. As shown by Noonan (1985:107-10), this particular type of constructions occurs with verbs of immediate perception, e.g. 'see' or 'hear'. In these clauses the entire phrase consisting of (pro)noun $+y n+$ verbal noun is analysed as a complement of the perception verb as it is the event of someone doing something that is perceived and not just the entity by itself (Noonan 1985: 130). However, Noonan (1985: 62-4) points out that for non-finite and particularly participial complements of verbs of immediate perception an adnominal interpretation cannot always be ruled out. The presentative constructions are closely connected to this type of complement relation as their trigger words llyma 'look here' and nachaf'lo, behold' are derived from verbs of immediate perception (cf. Evans 1964: 246). Thus, the group of presentative constructions is conflated with complement relations.

The remaining two types (adnominals and absolutes) continue to constitute separate classes. Hence, I propose four major types of non-aspectual uses of $y n+$ verbal noun:

- $\quad$ adjuncts (participant-oriented and co-eventive as types of secondary predicates)

- complements

- $\quad$ adnominal modifications

- absolutes

As I have already pointed out, the differentiation between perception complements and adnominal modification is not always clear-cut and open to debate. In the data analysis (section 3), however, the occurrence of a verb of perception together with $y n+$ verbal noun is treated as a formal criterion for the analysis as a complement relation. In a similar vein, absolute constructions may be analysed as adnominal modifications in other approaches. Yet, the occurrence of the conjunction $a(c)$ and ideally some anaphoric reference is understood as a formal feature to differentiate between these uses.

Taking the above classification as a point of orientation for Middle Welsh uses of $y n+$ verbal noun, the following section incorporates the first three types into a semantic study on secondary predication and highlights their interconnectedness. 


\section{A semantic map of secondary predicates}

This section aims to integrate the suggested classification of Middle Welsh uses of $y n+$ verbal noun in a typological framework which deals with semantic overlaps of predicative, complement, attributive and adverbial relations.

The study presented in van der Auwera \& Malchukov (2005) belongs to the vast area of studies of secondary predicates. Clauses containing two predicative constituents which remain separate from each other and do not form a complex predicate are understood as involving a secondary predicate. A secondary predicate is optional and not obligatory, unlike predicate complements the absence of which would render a sentence ungrammatical (Himmelmann \& Schultze-Berndt 2005). Much research on secondary predicates is concerned with the differentiation between adverbials and secondary predicates. The main distinction is found in the orientation of the two. Generally, adverbial adjuncts are event-oriented while secondary predicates are participant-oriented (Fabricius-Hansen \& Haug 2012:3) while both types still fall under the wider category of adjuncts. In other words, secondary predicates make a predication about a participant of the main predicate. In (11), smiling is a secondary predication to the agent of the main predication Deb, while in (12) and (13) secondary predications are made about the patients of the respective main predication. Himmelmann \& Schultze-Berndt (2005: 9) point out further that participant-oriented secondary predicates (i.e. depictives in their terminology) express a relation of temporal overlap.

(11) Deb stood smiling $_{\mathrm{i}}$ in the doorway.

(12) Deb drinks her tea $_{j}$ black $_{j}$.

(13) George ${ }_{i}$ bought the carrots fresh $_{j}$.

In contrast to other studies, van der Auwera \& Malchukov (2005) take adjectival secondary predicates (or depictives) as their starting point to exemplify their semantic closeness to other adjectival constructions such as simple adjectives, relative clauses and participles (see Fig. 1). Van der Auwera and Malchukov illustrate that, semantically, secondary predicates/depictives (DEP) stand between predicatives of main predications (in short predicative; PRED) and attributive uses (van der Auwera \& Malchukov 2005: 398-406). In their description they subdivide attributive uses into appositive (APP) and restrictive (RESTR) attributes. Depictives are similar to predicates in making a predication about a participant, but they stand apart from attributes, both restrictive and appositive, i.e. adnominal modifications, in that they do not identify a participant of a main predication.

Van der Auwera and Malchukov show that complements (COMPL) are closely 
connected with depictives as they also include two predications. The difference between complements and depictives is, however, that one of the predications in complements is subordinated, while the predication of a depictive belongs to the main predication and is thus on the same syntactic level. As complements may also occur with the copula, they draw a connection between predicatives and complements and position them on a par with depictives (van der Auwera \& Malchukov 2005: 406-10). With regard to complements to verbs of perception, van der Auwera and Malchukov emphasise that these constructions are very similar to patient/object depictives, and both interpretations are equally likely in these constructions (van der Auwera \& Malchukov 2005: 407).

As explained above, depictives are closely connected with adverbials (ADV), and depending on the orientation of the adjuncts (participant- vs. event-orientation) it is sometimes impossible to distinguish these two uses (van der Auwera \& Malchukov 2005: 410-1; Himmelmann \& Schultze-Berndt 2005). Himmelmann \& Schultze-Berndt follow a very specific definition of secondary predicates to describe depictives. As the distinction and the criteria for defining depictives in Himmelmann \& Schultze-Berndt 2005 are sometimes hard to capture for Middle Welsh, I apply the more neutral concept of 'participant-oriented' and 'co-eventive' adjuncts in the following. Both of them stand in contrast to 'event-oriented adjuncts' which describe what is commonly known as adverbials (of time, reason, condition etc.). While 'participant-oriented' adjuncts are understood as cases which show orientation to a participant of the superordinate clause and are co-temporal, 'co-eventive' adjuncts carry an additional circumstantial meaning, such as attending circumstance, instrument or cause.

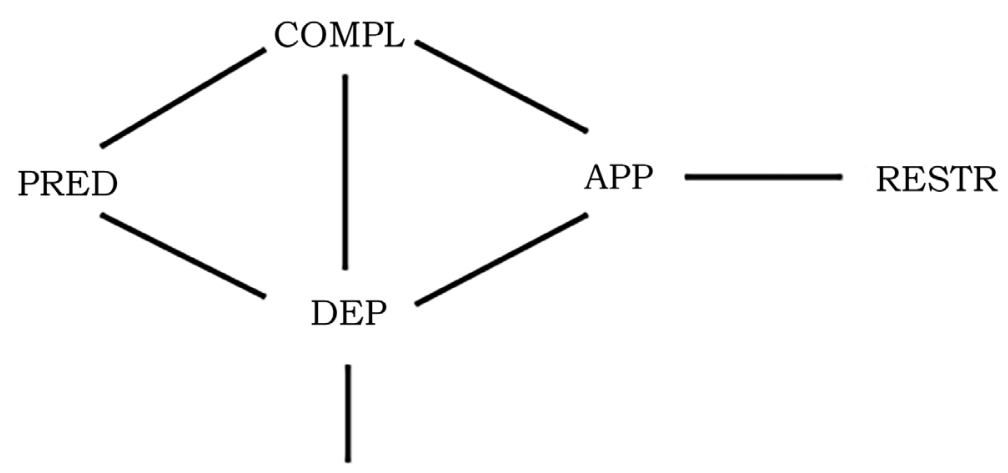

ADV

Fig. 1: Semantic Connections following van der Auwera \& Malchukov (2005) 
Having established these five uses of adjectival constructions, van der Auwera and Malchukov investigate the morphological properties languages employ to distinguish these five uses. While some languages use different morphological markers for certain uses, one of their sample languages is of particular interest for the analysis of Middle Welsh - this is the Indo-Aryan language Maithili. In Maithili the present participle can be used to express all five relations: predicative, complement, attributive (both restrictive and appositive), depictive and adverbial (van der Auwera \& Malchukov 2005: 419). Note that van der Auwera \& Malchukov (2005) also interpret periphrastic tenses as predicative uses.

Transferring their concept to the usage of Middle Welsh, we find that $y n+$ verbal noun can express four of the five areas, except clearly event-oriented adjuncts (subsumed under type D):

A. predicative, aspectual tense

Ac yna yd oed Allectus yn guneuthur gvylua y'v tatolyon dvweu yn Llunden.

And then Allectus was conducting festivals to their paternal gods in London.

(BD 66 V.4)

B. adnominal

Ac rac ruthur y bydinoed yn tewhau am eu pen. $y$ bu reit y'r amherawdyr ${ }_{\mathrm{i}}$ adaw $y_{\mathrm{i}}$ gledyf yn $y_{\mathrm{j}}$ daryan gan nynyaw . $_{\mathrm{j}}$

And because of the assault of the troops which was/were thickened around them it was necessary for the emperor to leave his sword in his shield with Nynyaw.

(BB-RB 72.12-5)

C. complement

...ef a welei varchawc yn dyfot yn y erbyn...

...he saw a knight coming towards him...

(P 61.17-8)

D. adjuncts participant-oriented

Ac yn yr amser hwnnw yd oedynt yn ynys brydein yn talu enryded y'r geudwyweu. Wyth temyl ar hugeint a their prif demyl.

And in that time there were in the island of Britain paying reverence to the false gods 28 temples and three main temples.

(BB-RB 87.41-4) 
E. co-eventive

Kany eill un tywyssawc kaffel budugolyaeth heb y wyr a ellygant eu gwaet yn ymlad drostaw. Since one prince cannot take victory without his men who gave their blood fighting under/for him.

(BB-RB 79.15-8)

Following the classification suggested above in section 1.2, van der Auwera and Malchukov's type A (aspectual uses) is disregarded in the following data analysis. Their semantic description insists on the close connection between depictives and aspectual phrases. This formal overlap between depictives and aspectual phrases is reflected in the corresponding constructions in Middle Welsh formed with $y n$.

Obviously, one construction proposed in the classification above is not considered in van der Auwera and Malchukov's semantic description: absolute clauses. These are defined on a syntactic level as a type of coordination strategy and are therefore outside the scope of van der Auwera and Malchukov's study. For reasons of completeness $y n+$ verbal noun phrases used as absolute clauses are also discussed in the following.

\section{Data}

My small case study uses data from Brut y Brenhinedd ('History of the Kings') taken from the Red Book of Hergest (Oxford Jesus College MS. 111), dating to the fourteenth-fifteenth century (Huws 2002:60). The text is accessible online via http://www.rhyddiaithganoloesol.caerdydd.ac.uk/en/ms-page.php?ms=Jesus111\&page $=8 \mathrm{v} \& \mathrm{l}=\mathrm{c} 31 \mathrm{l1}$ (Luft et al. 2013). Textual examples from the website are slightly adapted following common editorial practices, e.g. by inserting ' , , between a conjunction and the article or possessive pronoun and by adding a space between particle and verb, etc. The reference to the examples follows the column and line numbers provided on the website. The entire text covers 200 columns on 51 folios (i.e. folio 8 verso, column 31-folio 58 recto, column 230). For the current data set, I collected examples from 66 columns (folio 8 verso, column 31 to folio 24 verso column 96). This is about a third of the text. ${ }^{2}$

Brut y Brenhinedd is a highly influential translation of Geoffrey of Monmouth's De gestis Britonum commonly referred to as Historia Regum Britanniae ('The History of the Kings of Britain'). Geoffrey of Monmouth is supposed to have finished it between 1123 and 1139 (Reeve 2007). The Welsh translation has survived in a vast

2. The restriction of the length of the studied text is due to the research design; uses of $y n+$ verbal noun are a subset of my current $\mathrm{PhD}$ project on a classification of non-aspectual uses of preposition/ particle + verbal noun in Middle Welsh with regard to subordination strategies. The data used in the $\mathrm{PhD}$ project presents a revised set, however. 
number of manuscripts, with the earliest translations dating to the middle of the $13^{\text {th }}$ century (Roberts1977/1978: 147; Sims-Williams 2016: 54). The most recent appraisals of the relationship of the manuscripts are provided in Roberts $(2015,2018)$, SimsWilliams (2016), Lloyd-Morgan (2018), Lloyd-Morgan \& Roberts (2018). The Red Book of Hergest version comprises six manuscripts (Sims-Williams 2016: 59): NLW 3035B (Mostyn 116), BL Add. 19709 (both 14th c.), Philadelphia 8680, Jesus College MS. 111 (= Red Book of Hergest), Peniarth $19\left(14 / 15^{\text {th }}\right.$ c.) and Peniarth 263 (first half of the $15^{\text {th }}$ c.). Sims-Williams (2016: 59) also groups the manuscripts together according to the scribe or group of scribes working on them. From this perspective, NLW 3035B (Mostyn 116) and BL Add. 19709 form a subgroup as do the three manuscripts Philadelphia 8680, Jesus College MS. 111 and Peniarth 19. As the first two texts present a slightly earlier date of transmission and the latter three are closely connected in respect to their scribal practice, the four variant versions are consulted in the case of textual problems. The more distantly related, edited text of Brut Dingestow has been used for comparative purposes.

Within the sample I identified 71 instances of non-aspectual uses of $y n+$ verbal noun. The distribution is illustrated in Table 1 below. Complement relations constitute the most frequent use of non-aspectual $y n$ + verbal noun, with 31 examples (43.7\%) in my sample. For adjunct relations the sample provides 14 examples (19.7\%), followed by adnominal uses with 13 examples (18.3\%). Five instances are analysed as absolute constructions (7.0\%). There are two groups of overlapping categories (adjunct/adnominal with 4 cases (5.6\%) and one complement/adjunct/adnominal $(1.4 \%))$. The analysis of three example remains unclear (4.2\%).

Nearly a fifth of the constructions can be analysed as adjunct relations. Seven of them contain a locative phrase and are therefore classified as participant-oriented adjuncts, see (14). In most cases we find the predicate bod 'to be' as in (14), but there is one case which uses trigo 'live, stay' which also implies a state, see (15). In seven further examples the $y n$-phrases show a clear temporal overlap and participant-orientation, but also allow for circumstantial semantics. Thus they fall within the scope of co-eventive adjuncts, see (16).

(14) Phan ytoed allectus yn llundein yn gwneuthur gwyluaeu y dadolyon dwyweu... And when Allectus was in London making festivals for the paternal gods...

$\left(\mathrm{BB}-\mathrm{RB}\right.$ 92.18-20) ${ }^{3}$

3. In section 2 above, the parallel text of BD was cited to exemplify an aspectual use of $y n$. A comparison shows that the only difference is the constituent order which is a formal criterion here for the differentiation between aspectual and depictive constructions. 
Table 1: Distribution of $y n+$ verbal noun

\begin{tabular}{|c|c|c|c|c|}
\hline Relation type & Subcategory & $\begin{array}{l}\text { Count of } \\
\text { subcategory }\end{array}$ & Count & Percentage \\
\hline \multirow[t]{3}{*}{ adjunct } & & & 14 & $19.7 \%$ \\
\hline & $\begin{array}{l}\text { participant } \\
\text { oriented }\end{array}$ & 7 & & \\
\hline & co-eventive & 7 & & \\
\hline \multirow[t]{5}{*}{ complement } & & & 31 & $43.7 \%$ \\
\hline & perception & 11 & & \\
\hline & presentative & 2 & & \\
\hline & mirative & 15 & & \\
\hline & other & 3 & & \\
\hline adnominal & & & 13 & $18.3 \%$ \\
\hline absolute & & & 5 & $7.0 \%$ \\
\hline adjunct/adnominal & & & 4 & $5.6 \%$ \\
\hline $\begin{array}{l}\text { complement/ad- } \\
\text { junct/adnominal }\end{array}$ & & & 1 & $1.4 \%$ \\
\hline unclear & & & 3 & $4.2 \%$ \\
\hline sum & & & 71 & $100 \%$ \\
\hline
\end{tabular}

(15) ac yno y trigwys bran yn amberawdyr yn rufein yn gwneuthur yr arglwydiaet yno kynno hynny ar creulonder

And then Bran stayed as emperor in Rome making the government there [before that such an oppressions as this]

(BB-RB 64.19-22) 
(16) A cheissaw mynet drwy auon a oed gyr eu llaw. sef oed y henw akalon. ac yn keissaw bryssyaw drwy yr auon y periglwys aneiryf onadunt.

And they tried to wade through the river which was close by, of the name Ascalon, and trying to hasten through the river, a great multitude of them was in danger.

(BB-RB 34.32-5)

All of the 14 examples analysed as secondary predicates show agent-orientation. Furthermore, secondary predicates can be found in both finite (main and subordinate clauses) and non-finite phrases with the verbal noun. ${ }^{4}$

With regard to the position of adjuncts, (16) represents an exception, as it is one of two cases in the sample where the $y n$-phrase precedes its superordinate clause. It may well be that this is an instance of translational syntax. In the Latin text supplied in Reeve (2007), we find a parallel order of constituents, see (17). The gerundive phrase in transeundo precedes the main verb of the sentence which may have been the model for the Middle Welsh constituent order as yn keissaw bryssyaw with the addition of keissaw 'try'. The use of keissaw 'try' in this phrase resumes a cheissaw mynet in the preceding Welsh sentence. ${ }^{5}$

(17)

Porro Graeci confestim stupefacti in omnes partes dilabuntur et rege suo praecedente flunium Akalon, qui prope fluebat, transire festinant; at in transeundo infra uoraginem fluctus periclitantur.

The Greeks were immediately thunderstruck, fled in all directions and, led by their king, rushed to cross the river Akalon, which flowed near by; but as they crossed, they were at the mercy of its swirling waters.

(Reeve 2007: 11.113-5)

4. The remaining cases of participant-oriented adjuncts are BB-RB 32.27-9, 65.24-7, 73.14-6, 80.1720 and 87.41-4 and for co-eventive adjuncts BB-RB 32.30-3, 42.8-10, 54.22-8, 61.44-62.1, 79.15-8 and $87.9-12$.

5. The second example is

Sef a oruc brutus anelu bwa a gellwg saeth ac yn keissaw llad y karw y brathawdy dat a'r saeth $y$ adan y vron ac y bu uarw.

This is what Brutus did: he aimed the bow and let an arrow go and in trying to kill the stag he pierced his father with the arrow from under his breast and he died.

(BB-RB 32.30-3)

Here, the Latin text does not provide a parallel passage. In this case, the position before the main clause may be intended to draw attention to the unintended killing rather than a murderous act by Brutus. 
Complement relations account for $43.7 \%$ of the overall data (31 exx.). ${ }^{6}$ Within this group the bulk of the data is constituted by complements of perception (28 exx.) including complements to verbs of immediate perception (11 exx.), and both presentative and mirative constructions ( 2 and 15 exx. respectively). The 11 examples of complements to verbs of immediate perception only use the matrix verb gwelet 'see', although other verbs of immediate perception such as clybot 'hear' seem equally possible. All of the mirative and presentative constructions (17 exx.) are introduced by nachaf 'lo, behold' in my sample from Brut y Brenhinedd. (18) is a mirative construction where the order within the nachaf-phrase is inverted as the $y n+\mathrm{VN}$-phrase precedes the noun phrase. This inversion may be explained by the law of increasing terms (or constituents) (Behaghel 1909; Behaghel 1932: 234).

(18) a phan ytoed yn dyuot parth ac ynyssed prydein. nachaf yn kyuaruot ac wynt dec llog ar hugeint yn llawn o wyr a gwraged and when he came to the British Isle, behold meeting them, 30 ships full of men and women

(BB-RB 65.17-20)

The complement clauses of gwelet 'see' appear in different syntactic surroundings, which suggests that they are not restricted by the syntactic level of their matrix verb. My data set includes examples of the $y n$-phrase as a complement to main and subordinate clause predicates and to non-finite uses of gwelet, see (19)-(21).

(19) ... y gwelei y dwywes yn seuyll rac y vron ac yn Dywedut wrthaw val hynn. ...he saw the goddess standing before him and speaking to him like this.

(BB-RB 41.3-5)

(20) A phan wyl gwyr rufein y brytanyeit yn dyuot attunt. gwisgaw eu harueu a wnaethant. And when the men of Rome saw the British coming towards them they took up their arms.

(BB-RB 77.29-31)

6. The cases for presentatives are $\mathrm{BB}-\mathrm{RB} 46.2-6,46.2-7$ and for mirative constructions $\mathrm{BB}-\mathrm{RB}$ 32.29-30, 36.37-41 (3 coordinated $y n$-phrases), 36.49-53 (2 coordinated $y n$-phrases), 59.21-4, 59.28-32 (2 coordinated $y n$-phrases), 64.2-9, 65.17-20, 77.25-6, 82.17-9, 84.39-42 (2 coordinated yn-phrases). Cases of perception complements with gweled are BB-RB 41.15-8, 41.3-5 (two coordinated yn-phrases), 61.36-41, 62.10-3, 63.14-9, 72.1-2, 77.29-31 within finite structures; the non-finite examples are BB-RB 45.43-5, 63.34-40 and 88.38-41. Other types of complementation are BB-RB 34.51-35.1, 37.51-3 and 96.29-33. 
(21) A gwedy gwelet o les diwyllwyr cristonogawl fyd yn kynydu yn y deyrnas. Diruawr lewenyd a gymerth yndaw.

And after Lles saw worshippers of the Christian faith increasing in his kingdom great joy took him.

(BB-RB 88.38-41)

The remaining three complement relations use the verbs gorffwysaf 'rest, desist' (twice) and adaw 'leave' (once); cf. (22) and (23). In these complement relations the $y n$-phrase fills an argument position demanded by the respective verbs.

(22) $Y$ dorof. [f.] a oed ygyt ac ynteu. ny orffwyssei honno ${ }_{\mathrm{i}}$ yn llad heb drugared a gyfarffei a hi. His troops ${ }_{i}$ which were with him, they ${ }_{i}$ did not desist killing without mercy those who met with them.

$(\mathrm{BB}-\mathrm{RB} 37.51-3)^{7}$

(23) Ac yn yr amser hwnnw y kyuodes eudaf iarll ergig ac euas yn erbyn y tywyssogyon ${ }_{\mathrm{i}}$ a ry

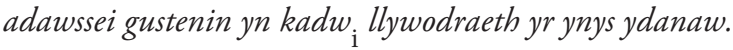

And in this time Eudaf, earl of Ergig and Yefas, rose up against the princes, whom Constantine had left guarding ${ }_{\mathrm{i}}$ the government of the island under him.

(BB-RB 96.29-33)

(23) is particularly interesting as the noun phrase $y$ tywyssogyon 'the princes', the object of the main clause, is the unexpressed agent of the complement clause $y n k a d w$ llywodraeth yr ynys ydanaw 'guarding the government of the island under him'. As a result of movement, the agent of the complement phrase has to be inferred from the preceding main clause (cf. Willis 1998: 78-90 for topicalisation from within a constituent and for movement in relative clauses). ${ }^{8}$

7. In this case, gorffwysaf is analysed as a phasal predicate with the meaning 'stop, desist from' and thus as a complement-taking predicate (cf. Noonan 1985). Interestingly, the verbal noun phrase is introduced with $o(c)$ in Mostyn 116, 29r, and BL Add. MS 19,709, 11v, which is generally a more common marker for complementation than $y n$. Since this constructional question remains, the use of $y n$ with gorffwysaf needs further investigation. As the context infers a phasal interpretation, this example is classified as complementative.

8. From a comparative perspective, this represents an example of prolepsis or raising (Lehmann 1988: 201f). 
Adnominal relations make up $18.3 \%$ of the collected data with 13 examples. 9 Interestingly, but also problematically, three examples appear in one complex sentence at the beginning of Brut y Brenhinedd in the description of the island of Britain. These examples are discussed separately in section 4 below to exemplify the semantic proximity of construction types. Further three examples appear to be translations of an opening of letters in Latin like Pandraso regi Graecorum Brutus dux reliquiarum Troiae salutem 'Brutus, leader of the survivors from Troy, sends greetings to Pandrassus, king of the Greeks' (Reeve 2007: 9.92), or similar phrases with the meaning ' $X$ sending greetings to $Y$ ', see (24), for which an adnominal analysis seems most natural. The following two examples, (25) and (26), are both appositive modifications to the noun phrases (ruthur y) bydinoed '(the assault of) the troops' and gwasanaethwyr 'servants'.

(24) Kaswallawn brenhin y brytanyeit yn anuon annerch y ulkessar.

Caswallawn, king of the British who sends greetings to Cesar.

(BB-RB 70.28-30)

(25) Ac rac ruthur y bydinoed yn tewhau am eu pen. y bu reit y'r amberawdyr adaw y gledyfyn $y$ daryan gan nynyaw.

And because of the assault of the troops which was/were thickened around them it was necessary for the emperor to leave his sword in his shield with Nynyaw.

(BB-RB 72.12-5)

(26) A gwedy bot llyr yn y wed honno gyt a maglawn. blyghau a oruc cordeilla rac meint oed o varchogyon gyt ae that ac rac eu gwasanaethwyr wynteu yn teruysgu y llys.

And after Lear was like this with Maglawn, Cordeilla grew angry because of the number of knights with her father and because of their servants who disturbed the court.

(BB-RB 53.21-6)

The text excerpt provides five examples (8.3\%) of absolute clauses. ${ }^{10}$ As the number of absolute constructions in the sample is low, the following should be considered as observations and tentative remarks which need to be investigated further when more data is available.

9. The cases of appositive adnominal modification are BB-RB 31.12-6, 31.33-6, 31.34-6, 31.36-40, $33.38-42,35.40-5,53.21-6,57.9-10,70.28-30,72.12-5,73.12-4$ and $76.17-9$, and only one restrictive use in BB-RB 86.3-4.

10. These are BB-RB 33.11-5 (two yn-phrases), 52.37-40, 78.22-9, 79.43-80.1 
Following Mac Cana's (1999) analysis, the expected structure involves the conjunction $a(c)$, a pronoun and $y n+$ verbal noun. ${ }^{11}(27)$ follows this pattern with a pronominal resumption of an actant of the preceding clause (kaswallawn resumed as ynteu). In contrast to this, the agent of the verbal noun phrase is left implicit in (28) and has to be inferred from the preceding context, i.e. in this case the subject of the main clause $y$ gwas Jeuanc. Mac Cana considers constructions as illustrated in (28) as irregular (Mac Cana 1999: 162-8), while regular constructions involve pronominal resumption. The typological considerations of participial adjunct and absolute constructions by König \& van der Auwera (1990) show that different patterns of the expression of participants are to be expected and implicit agents as in (28) are not unusual.

(27) Nyt ef a wnel creawdyr nef a dayar diodef ohonaf $i$ karcharu kaswallawn ${ }_{\mathrm{i}}$ uy arglwyd. ac ynteu $\mathrm{i}_{\mathrm{i}}$ gwneuthur iawn imi am y sarhaet a wnaethoed ymi.

May the creator of heaven and earth forbid that I suffer the imprisonment of Caswallawn $_{\mathrm{i}}$, my lord, and he doing justice to me for the wrong which he had done to me.

(BB-RB 79.43-80.1)

(28) Ac ygyt a hynny hefytyd oed y gwas Jeuanc bonhedickafyg groec o barth y dat. y vam ynteu a hanoed o genedyl droea. ac yn ymdiret yndunt ac yn gobeithaw kael nerth mawr y gantunt. And moreover, the young man was the most noble in Greece from his father's side, his mother was descended from the cenedl of Troy, and he had confidence in them [the cenedl of Pyrrhus] and he hoped to gain much strength from them.

(BB-RB 33.11-5)

In addition to these clearly assigned cases, we find five examples that are ambiguous in their classification. In four cases, it cannot be ascertained whether the $y n$-phrase is an adjunct or an adnominal modification as illustrated in (29) and (30). ${ }^{12}$ The sentence-final position of the $y n$-phrase following its head noun in (29) makes it unclear whether the $y n$-phrase should be interpreted as a participant-oriented adjunct or an adnominal modification. In (30), the position of the $y n$-phrase is unclear whether it belongs to the finite prepositional relative clause ( $y n$ y lleoed...) as a participant-oriented adjunct or should be interpreted as an adnominal modification of bedeu.

11. Note that Richards (1938:26) also mentions the use of nouns proper in absolutes.

12. The other two cases are BB-RB 42.15-8 and 63.14-9. 
(29) ac ar hyt y rei hynny y deuant amryvael gyfnewityeu. or gwladoed tramor. ac y gyt a hynny gynt yr oed yndi wyth prif dinas ar hugeint yn y theckau

and along these [arms of the river] different kinds of trade of foreigns lands come up and together with these there were formerly 28 principal cities in her [the British Isle] adorning her

(BB-RB 31.28-32)

(30) Ac yr awr hon y mae bedeu y rei hynny ac eu hescyrn ac eu creireu yn y lleoed y merthyrwyt yn gwneuthur diruawr wyrtheu a didanwch y'r neb a edrychei arnadunt.

And presently there are graves of these and their bones and their relics in the places where one martyred [them] making enormous miracles/wonders and delight to anyone who would have looked on them.

(BB-RB 94.9-13)

(31) A gwedy kaffel oheni ef yn kysgu yd aeth hi ae morynyon ae lad.

And after she found him sleeping, she went with her maidens and killed him.

(BB-RB 57.27-9)

The phrase efyn kysgu in (31) is constructionally similar to phrases classified as complements of immediate perception. The semantics of cael 'get, obtain, find' in this example may be analysed as a knowledge predicate in the sense of 'discover' which shows complementation patterns (cf. Noonan 1985 and Cristofaro 2003). In addition, we can detect participant-orientation. Similar to the cases of adjunct/adnominal modification above, the order of the constituents may suggest an adnominal reading.

The sample yields three unclear cases with regard to the above criteria. ${ }^{13}$ (33) is given here as an example. On the first sight, (33) fulfils the criteria for a participant-oriented adjunct with two temporally overlapping actions, belonging to the group with an intervening locative.

(32) Kany wdant beth yw milwryaeth wrth eu bot y mywn eigawn odieithyr y byt yn presswylaw. Because they don't know what warfare is as they are in the ocean outside the world dwelling/residing.

(BB-RB 70.11-4)

13. The other two unclear cases are BB-RB 36.30-4 and 82.23-31. In the former the semantic relation is not clear, while in the latter the syntax of the clause is faulty. 
On further analysis, however, this textual example should rather be considered as being positioned on the border between participant-oriented and aspectual construction. The two predications involved here are bod 'be' and presswylaw 'live, dwell'. Semantically, 'being' and 'dwelling' are very close, and it seems unclear whether such a semantic closeness can still result in a participant-oriented adjunct with two separate, but temporally overlapping actions.

\section{Discussion}

As has become apparent in the previous sections, the classification of $y n$-phrases into complement, secondary predicate and adnominal relations as three of the five types proposed in van der Auwera \& Malchukov (2005) results in some uncertainties.

As mentioned above, three examples of adnominal relations are discussed here in more detail. They appear in a complex clause which shows syntactic difficulties in the Red Book version; see (33).

(33) Ac ygyt a hynny gynt yr oed yndi wyth prif dinas ar hugeint yn y theckau. a rei onadunt

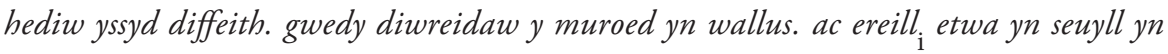
iach. a themleu seint yndunt $t_{\mathrm{i}}$ yn moli duw. a muroed a chaeroed arderchawc yn eu $u_{\mathrm{i}}$ teckau. ac yn y temleu kenueinoed o wyr a gwraged a chwuenoed yn talu gwassanaeth dylyedus yn amseroed keugant y eu creawdyr yn herwyd cristonogawl fyd.

And together with these there were formerly 28 principal cities in her [the British Isle] adorning her and some of them are desolate today, after their walls were destroyed carelessly, and others are still standing safely with temples of saintly people in them who praise god and walls with raised citadels which adorn them and in the temples groups of men and women and religious communities who donate proper sacrifice at the appropriate time to their creator according to the Christian faith.

(BB-RB 31.30-40)

a) a themleu seint yndunt ${ }_{\mathrm{i}}$ yn moli duw.

b) a muroed a chaeroed arderchawc yn eu teckau.

c) ac yny temleu kenueinoed o wyr a gwraged a chwuenoed yn talu gwassanaeth dylyedus yn amseroed keugant y eu creawdyr yn herwyd cristonogawl fyd.

Examples (31a) and (31b) have been classified as adnominal rather than as secondary predicates as neither modify a main participant of the clause and are thus not participant-oriented. ${ }^{14}$ However, the constituent order in (31a) seems odd as the locative yndunt 'in them' referring back to the principal cities is placed between the

14. The $y n$-phrase in ereill, etwa yn seuyll yn iach is understood as co-ordinate with rei onadunt hediw yssyd diffeith. with an omission of yssyd as the finite form of bod. 
head of the $y n+$ verbal noun phrase. As (32c) further describes the temples which have been mentioned previously, a superordinate state of affairs cannot be adduced for $y n+\mathrm{VN}$ so that a depictive reading has to be excluded.

The more distantly related Brut Dingestow version is clearer here as it uses clear periphrastic constructions with ysyd and maent (cf. (34)). An insertion of maent in (31b) would clearly help the syntax, but the three other versions ${ }^{15}$ transmit it parallel to the Red Book. These clauses may be understood as grammatically correct structures rather than faulty copies of their particular exemplars. It is obvious, however, that these textual problems are an additional factor, besides the semantic overlap of the constructions, which blurs the analysis of some of the occurrences of $y n+\mathrm{VN}$.

(34) Ereyll etwan ysyd yn seuyll yn gyvan ac yn gyweir o wuroed cadarn goruchel arderchavc, yn y rei y maent amraualyon genueinyoed gvyr a gvraged yn talu gouunedavl wassanaeth y'r creavdyr yn herwyt fydlavn Gristonogaeth.

Others are still standing complete and proper of strong walls of raised citadels in which different kinds of religious communities of men and women are donating devoted services to their Creator according to the Christian faith.

(BD I.2)

As discussed above, $y n$-phrases following the direct object of a verb of immediate perception can be analysed in different ways, as adjuncts, complements or attributes, cf. Borsley et al. (2007: 303), Noonan (1985: 62-4). Both the semantic overlap of perception complements and secondary predicates and their intermediate position between predicative and attributive constructions is addressed by van der Auwera \& Malchukov (2005: 406-10). The Middle Welsh examples mirror the observations of van der Auwera \& Malchukov (see (35) below again for an illustration). In constructions with a verb of immediate perception (e.g. gwelet $+\mathrm{N}+y n+\mathrm{VN})$ three analyses compete:

a) the $y n+\mathrm{VN}$ may be analysed as a modification of the preceding noun

b) the object phrase may be analysed as a complement $(\mathrm{N}+y n+\mathrm{VN})$

c) the $y n+\mathrm{VN}$ may be analysed as a depictive which is participant-oriented (here patient-oriented)

As emphasised by van der Auwera \& Malchukov (2005: 406-10), a clear-cut analysis is often impossible. Due to these problems, formal characteristics have been established here. In the above analysis, the co-occurrence of a verb of immediate perception and an $y n$ phrase were regarded as the decisive factor.

15. The manuscripts are NLW 3035B (Mostyn 116), Philadelphia 8680, Peniarth 19; BL Add. 19709 leaves out this passage. 
(35) Gwedy y weledigaeth honno dyffroi a wnaeth brutus a phetrussaw beth ry welsei ae breidwyt ae dwywes yn menegi idaw ynteu y lle a bresswylei.

After his vision Brutus woke up and was unsure whether he had seen a dream or a goddess explaining to him where he should dwell / or a goddess who explained to him where he should dwell.

(BB-RB 41.15-8)

For the differentiation between aspectual constructions (a type of predicative use according to van der Auwera \& Malchukov 2005) and participant-oriented adjuncts, I followed Mittendorf \& Poppe (2000) in taking an intervening locative as a formal factor in favour of the analysis as secondary predicates (participant-oriented adjuncts). Further study is needed to specify possible additional factors which help to differentiate these two uses, which so far have not been distinguished.

As mentioned above, the differentiation between participant-oriented and co-eventive adjuncts is sometimes difficult, if not impossible. While for modern languages, language intuition may help to distinguish a purely temporal overlap (participant-oriented or strict depictive reading) from further nuances (co-eventive and adverbial reading), this cannot be applied to Middle Welsh. Thus, the semantic overlap between secondary predicates (participant-oriented and co-eventive adjuncts) and event-oriented adjuncts seems to be fuzzier in Middle Welsh than the semantic intersections of the other types. Yet, it is precisely these uncertainties which mirror the semantic intersections of these five types as explained in van der Auwera \& Malchukov (2005). The semantic fuzziness of $y n$-phrases makes them the more intriguing and leaves room for further surveys which should focus on other syntactic, semantic and pragmatic factors.

\section{Summary}

Van der Auwera \& Malchukov (2005) show that predicative (including aspectual), complement, depictive, adverbial and adnominal constructions show close semantic links. As demonstrated above, their observations also hold true for Middle Welsh constructions with the particle $y n+$ verbal noun. Clauses which use bod 'be' or an inflected form of it together with $y n$ + verbal noun may not always be analysed simply as aspectual constructions. It has been shown that other formal criteria concerning the word order and the appearance of locative phrases influence the analysis and make a reading as a participant-oriented adjunct (i.e. secondary predicate) more likely. Cross-linguistically, complement relations, particularly complements to verbs of immediate perception, show fuzziness as they may also be read as participant-oriented adjuncts or adnominal constructions.

In this light, Middle Welsh constructions with $y n+$ verbal noun exemplify the notion of 'hidden complexity' as described in Bisang (2009, 2014, 2015). In contrast 
to 'overt complexity', the explicit articulation of features or patterns, 'hidden complexity' is defined by pragmatic inference and language economy. Elaborating on this, Bisang explains that the hidden side of complexity is expressed, for example by multifunctional markers whose "concrete meaning must be pragmatically inferred" (Bisang 2014: 129). Thus, "[h]idden complexity can generate grammars that produce morphosyntactic structures which are very simple from the perspective of overt complexity but need a lot of inferential work for being decoded" (Bisang 2014: 129). As has been shown above, $y n+$ verbal noun is used in a variety of relations which at first may simply be classified as the use of the particle $y n$ with the verbal noun, but its context-specific meaning cannot simply be inferred from this morphosyntactic pattern. For Middle Welsh, hidden complexity will be a valuable concept to understand and to describe structures which use the same constituents at the surface level. The description provided here clearly underlines the status of $y n$ as a multifunctional marker of type (i) in Bisang's definition: "A linguistic sign is multifunctional (i) if one and the same sign has more than one function within the same construction or if (ii) one and the same sign has more than one function because it can be assigned to more than one construction" (Bisang 2014:131). Viewed from the surface structure, the different types of $y n$ (predicative, adverbialising particle with verbal nouns and preposition cf. Sims-Williams 2015) may qualify as a type (ii) multifunctional marker. ${ }^{16}$ Further research is obviously needed to verify these considerations and position them in a wider context.

Philipps-Universität Marburg

\section{Abbreviations}

BB-RB - Luft, D., Thomas, P. W. \& Smith, D. M., 2013, Brut y Brenhinedd, available at http://www.rhyddiaithganoloesol.caerdydd.ac.uk/en/ms-page.php?ms=Jesus111\&page=8v, accessed 05 April 2019.

BD - Lewis, H., 1975, Brut Dingestow, Cardiff.

BDe-Evans, D. S., 1988, The Welsh Life of St David, Cardiff.

P-Goetinck, G. W., 1976, Historia Peredur vab Efrawc, Cardiff.

PKM - Williams, I., 1951, Pedeir Keinc Y Mabinogi. Allan o Lyfr Gwyn Rhydderch, Cardiff (2nd ed.).

16. This is a tentative suggestion and admittedly neglects the different etymologies and mutation patterns following the four different types of $y n$. 


\section{References}

Anwyl, E., 1899, A Welsh Grammar for Schools. 2: Syntax, London/New York. Van der Auwera, J., \& Malchukov, A., 2005, 'A Semantic Map for Depictive Adjectivals', in:Himmelmann, N. \& Schultze-Berndt, E. F., eds., Secondary Predication and Adverbial Modification. The Typology of Depictives, Oxford/New York, 393-421.

Behaghel, O., 1909, 'Beziehungen zwischen Umfang und Reihenfolge von Satzgliedern', Indogermanische Forschungen 25, 110-42.

Behaghel, O., 1932, Deutsche Syntax: eine geschichtliche Darstellung. Vol. 4. Wortstellung und Periodenbau. Heidelberg.

Bisang, W., 2009, 'On the Evolution of Complexity: Sometimes Less Is More in East and Mainland Southeast Asia', in: Sampson, G., Gil, D. \& Trudgill, P., eds., Language Complexity as an Evolving Variable, Oxford, 34-49.

Bisang, W., 2014, 'Overt and Hidden Complexity - Two Types of Complexity and their Implications', Poznań Studies in Contemporary Linguistics 50.2, 127-43.

Bisang, W., 2015, 'Hidden Complexity - The Neglected Side of Complexity and Its Implications', Linguistic Vanguard 1.1, 177-87.

Borsley, R. D., Tallerman, M., \& Willis, D., eds., 2007, The Syntax of Welsh, Cambridge. Cristofaro, S., 2003, Subordination, Oxford.

Evans, D. S., 1964, A Grammar of Middle Welsh, Dublin.

Evans, D. S., 1988, The Welsh Life of St David, Cardiff.

Fabricius-Hansen, C., \& Haug, D., 2012, 'Introduction', in: Fabricius-Hansen, C., \& Haug, D., eds., Big Events, Small Clauses. The Grammar of Elaboration. Berlin/ Boston, 1-17.

Falileyev, A., 1994, 'Notes on the Syntax of Middle Welsh Verbal Noun: Combinations with Aspect Markers', ZcP 46, 203-12.

Gagnepain, J., 1963, La syntaxe du nom verbal dans les langues celtiques. Irlandais, Paris. Goetinck, G. W., 1976, Historia Peredur vab Efrawc, Cardiff.

Himmelmann, N. \& Schultze-Berndt, E. F., 2005, 'Issues in the Syntax and Semantics of Participant-oriented Adjuncts', in:Himmelmann, N. \& Schultze-Berndt, E. F., eds., Secondary Predication and Adverbial Modification. The Typology of Depictives, Oxford/New York, 1-67.

Huws, D., 2002, Medieval Welsh Manuscripts, Aberystwyth.

König, E. \& van der Auwera, J., 1990, 'Adverbial Participles, Gerunds and Absolute Constructions in the Languages of Europe', in: Bechert, J., Bernini, G., \& Buridant, C., eds., Towards a Typology of European Languages, Berlin/New York, 337-55.

Lambert, P.-Y., 1978, 'Emplois dissymétriques de la coordination II. Problèmes soulevés par la prép. galloise â ag « avec », Études Celtiques 15.2, 523-31.

Lambrecht, K., 1994, Information Structure and Sentence Form. Topic, Focus, and the Mental Representations of Discourse Referents, Cambridge. 
Lehmann, Ch., 1988, 'Towards a Typology of Clause Linkage', in:Haimann, J., \& Thompson, S., eds., Clause Combining in Grammar and Discourse. Amsterdam/ Philadelphia, 181-225.

Lewis, H., 1975, Brut Dingestow, Cardiff.

Lloyd-Morgan, C., 2018, 'Un manuscrit illustré de Brut y Brenhinedd. Aberystwyth, National Library of Wales, Peniarth 23C', in: Tétrel, H., \& Veysseyre, G., eds., L"Historia regum Britannie" et les "Bruts" en Europe, Tome II. Production, circulation et réception (XIIe-XVIe siècle), Paris, 429-48.

Lloyd-Morgan, C. \& Roberts, B. F., 2018, 'Annexe. Répertoire de manuscrits de Brut y Brenhinedd', in:Tétrel, H., \& Veysseyre, G., eds., L"Historia regum Britannie" et les "Bruts" en Europe, Tome II. Production, circulation et réception (XIIe-XVIe siècle), Paris, 493-9.

Luft, D., Thomas, P. W., Smith, D. M., 2013, Brut y Brenhinedd.

(available at http://www.rhyddiaithganoloesol.caerdydd.ac.uk/en/ms-page.php?ms=Jesus111\&page $=8 \mathrm{v}$, last accessed 05.04.2019).

Mac Cana, P., 1997, 'Notes on Periphrasis with Verbal Noun and Verb 'to do' in Middle Welsh', in: MacMathúna, S. \& Ó Corráin, A., eds., Miscellanea Celtica in Memoriam Heinrich Wagner. Uppsala, 183-96.

Mac Cana, P., 1999, 'Syntax and Style in Middle Welsh Prose: Notes on Periphrasis and Epitaxis', Celtica 23, 157-68.

Mezger, F., 1931, 'yn + Verbalnomen in den Zweigen des Mabinogi', Zeitschrift für vergleichende Sprachforschung auf dem Gebiete der Indogermanischen Sprachen 58.3/4, 238-47.

Mittendorf, I. \& Poppe, E., 2000, 'Celtic Contacts of the English Progressive?', in: Tristram, H.L.C., ed., The Celtic Englishes II, Heidelberg, 117-45.

Morris-Jones, J., 1955, A Welsh Grammar. Historical and Comparative, Oxford (reprint from 1913).

Noonan, M., 1985, 'Complementation', in:Shopen, T., ed., Language Typology and Syntactic Description. Vol. 2: Complex Constructions, Cambridge (1st ed.), 42-140.

Reeve, M. D., ed., 2007, Geoffrey of Monmouth. The History of the Kings of Britain. Woodbridge.

Richards, M. 1938, Cystrawen y frawddeg Gymraeg. Gwasg Prifysgol Cymru.

Roberts, B. F., 1977/1978, 'The Red Book of Hergest Version of Brut y Brenhinedd', Studia Celtica 12-13, 147-86.

Roberts, B. F., 2015, 'Brut y Brenhinedd, ms. National Library of Wales, Llanstephan 1 Version', in: Tétrel, H., \& Veysseyre, G., eds., L'Historia regum Britannie” et les "Bruts" en Europe, Tome I. Traductions, adaptations, réappropriations (XIIe-XVIe siècle), Paris, 71-80.

Roberts, B. F., 2018, 'A Web of Welsh Bruts', in:Tétrel, H., \& Veysseyre, G., eds., L"Historia regum Britannie" et les "Bruts" en Europe, Tome II. Production, circulation et réception (XIIe-XVIe siècle), Paris, 147-68. 
Ronan, P., 2006, Aspects of Verbal Noun Constructions in Medieval Irish and Welsh With Reference to Similar Constructions in Basque, PhD Thesis. Maynooth.

Ronan, P., 2012, 'Development of Periphrastic Tense and Aspect Constructions in Irish and Welsh', in: Davidse, K., Briban, T., Brems, L., Mortelmans, T., eds., Grammaticalization and Language Change. New Reflections, Amsterdam, 227-48.

Rouveret, A., 1994, Syntaxe du gallois: principes généraux et typologie, Paris.

Sasse, H.-J., 1987, 'The Thetic/Categorical Distinction Revisited', Linguistics 25, 511-80.

Scherschel, R., Widmer, P., \& Poppe, E., 2018, 'Towards a Multivariate Classification of Event-noun Constructions in Middle Welsh', Journal of Celtic Linguistics 19, 31-68. Schultze-Berndt, E. F., \& Himmelmann, N. P., 2004, 'Depictive secondary predicates in crosslinguistic perspective', Linguistic Typology 8.1, 59-131.

Schumacher, S., 2000, The Historical Morphology of the Welsh Verbal Noun, Maynooth. Shisha-Halevy, A., 1999, 'Structural Sketches of Middle Welsh Syntax (II)', Studia Celtica 33, 155-234.

Shisha-Halevy, A., 2009, 'Converbs in Welsh and Irish. A Note', in: Zimmer, S., ed., Kelten am Rhein. Akten des dreizehnten Internationalen Keltologiekongresses. Proceedings of the Thirteenth International Congress of Celtic Studies. 23. bis 27. Juli 2007 in Bonn. Zweiter Teil. Philologie. Sprachen und Literaturen, Mainz, 269-77.

Shisha-Halevy, A., 2016, 'Work Notes on Modern Welsh Narrative Syntax (II): Presentatives in Narrative,' Journal of Celtic Linguistics 17, 97-146.

Sims-Williams, P., 2015, 'The Four Types of Welsh yn', Transactions of the Philological Society 113.3, 286-304.

Sims-Williams, P., 2016, 'The Welsh Versions of Geoffrey of Monmouth's 'History of the Kings of Britain”, in: Harlos, A. \& Harlos, N., eds., Adapting Texts and Styles in a Celtic Context, Münster, 53-74.

Sturzer, N., 2001, 'How Middle Welsh Expresses the Unexpected', CMCS 41, 37-53. Williams, I., 1951, Pedeir Keinc Y Mabinogi. Allan o Lyfr Gwyn Rhydderch, Cardiff (2nd ed.).

Willis, D. W. E., 1998, Syntactic Change in Welsh. A Study of the Loss of Verb-Second. Oxford. 
